\title{
Well-Being Indices Comparative Analysis: Russia and Foreign Countries
}

\author{
L.Yu. Spitsina ${ }^{a *}$, V.V. Spitsin ${ }^{b}$, A.A. Shashkova ${ }^{c}$ \\ * Corresponding author: Spitsina L.Yu., s_luba_07@mail.ru \\ ${ }^{a}$ Tomsk Polytechnic University, Lenina Avenue, 30,634050,Tomsk, Russia, E-mail address: s_luba_07@mail.ru, Tel.: +7-909- \\ 549-3711
}

\begin{abstract}
http://dx.doi.org/10.15405/epsbs.2016.02.57

Using the OECD's data, we study well-being indices comparison main areas for Russia and economically developed countries. The tendency of unleading countries to find mechanisms of economic growth by the welfare various aspects impact is noted. We used the method of complex efficiency estimation to solve the problem of economic well-being analysis. We assessed the effectiveness and optimality of economic well-being of the population. The effectiveness assessment of economic well-being in Russia revealed a significant gap from foreign countries by most indices. The optimality assessment of economic well-being did not reveal any major differences in values between men and women both in Russia and in foreign countries, but allowed to establish a greater gap between the values of indicators of leading and lagging groups in Russia than in other countries. Indicators ratio of lagging groups in Russia with foreign countries was worse than the ratio of indicators at the entire population level. The results of the economic well-being analysis are advisable to consider in the process of state regulation in Russia. State support of social services should be a priority of social and economic policy on the federal and regional authorities. Our analysis justifies the recommendation to reduce the gap between rich and poor groups of Russia's population by using various regulatory tools, including a progressive scale for a number of taxes.
\end{abstract}

(C) 2016 Published by Future Academy www.FutureAcademy.org.uk

Keywords: Well-being, complex efficiency, method of estimation, effectiveness, optimality, Russia, foreign countries.

\section{Introduction}

Well-being rates measurements are based on two types of indices. The first ones are connected with the windividual subjective opinions about personal happiness and life satisfaction. The second type oppositely assesses the real measurable aspects of economic welfare: personal incomes, property, dwelling expenses. All indices are complex and in the aggregate reflect real situation. The analysis of particular indicators helps the authorities to work out an adequate strategy for further development. The 
indices are graduated for groups of population by income, gender, age, health and education. The internal and international comparisons are popular last years in the world. Their results become a foundation for economic policy of the states (Diener, 2002, 2009; Dolan, 2008; Easterlin, 2001; Ferrer-i-Carbonell, 2005; Sarracino, 2013).

Despite the statistical confirmation of the conclusion of scientists that high income is not a guarantee of happiness (Mentzakis, 2009), the general welfare of the population certainly affects on the economic well-being. Anyone in any economic system must be able to maintain its vital functions, support a family and develop their abilities. The unleading countries try to find mechanisms for raising living standards and shaping socially oriented national economic development strategy (Asian and Eastern Europe countries). The researchers of these countries are actively perform the comparative analysis of quality of life according to national circumstances, mentality, culture, and philosophy of life (Han, 2015; Akter, 2014; Rajan, 2013).

\section{Methodology}

The authors have used structuring, typology, comparison, analogy, system analysis. Author's methodological approach of complex efficiency assessment was used to analyze integratively the effectiveness of complex social and economic facilities. The main provisions of the methodology set forth in the works (Spitsina, 2015; Spitsin, 2014). Now we describe its basic principles.

We apply a wide number of indicators for effectiveness assessment and for comparisons of the studied object with other objects. We consider the result as the important efficiency characteristic. It is the ratio of the result with other indicators allows us to speak about the efficiency. So the necessary and sufficient components of complex efficiency are:

- $\quad$ Effectiveness, defined as the evaluation of the result and its consistency with the expectations.

- Fecundity, termed as the ratio of the result and costs of resources.

- Optimality, ment as the optimal structure of the system, which allows to increase the effectiveness and fecundity of its operations.

Due to the limited number of indicators available for investigation in this paper we will only assess the effectiveness and optimality of social and economic well-being of the population. Our studied object is population of Russia and its welfare indicators compared with the same ones in USA, Germany, France and the average data of OECD countries at 2013 - 2014. We used the indicators of OECD Better Life Index (assessed by 38 leading countries) which allow to compare a lot of subjective and objective aspects of well-being (35 indicators).

Assessing the effectiveness we'll compare results (economic welfare indicators' data) of Russia and foreign countries and their changes in dynamics.

Evaluating the optimality we'll study the level of data differences of Russia and foreign countries to identify indicators with the highest lag of Russian ones at the following groups of people:

- Total population

- Population in gender

- $\quad$ Gap between the leading group and the lagging groups. 
The analyzed indicators based on OECD well-being data (http://stats.oecd.org/\#) are described at tab. 1.

Table 1. Economic welfare indicators studied

\begin{tabular}{|c|c|c|}
\hline $\begin{array}{l}\text { Indicator's } \\
\text { number }\end{array}$ & Indicator's name & Definition \\
\hline 1 & $\begin{array}{l}\text { Dwellings without basic } \\
\text { facilities }(\%)\end{array}$ & $\begin{array}{l}\text { refers the population living in a dwelling without indoor flushing toilet for the } \\
\text { sole use of their households. Flushing toilets outside the dwelling are not to be } \\
\text { considered in this item. Flushing toilets in a room where there is also a shower } \\
\text { unit or a bath are also counted. }\end{array}$ \\
\hline 2 & Housing expenditure (\%) & $\begin{array}{l}\text { refers to the number of rooms (excluding kitchenette, scullery/utility room, } \\
\text { bathroom, toilet, garage, consulting rooms, office, shop) in a dwelling divided by } \\
\text { the number of persons living in the dwelling. }\end{array}$ \\
\hline 3 & Rooms per person (Ratio) & $\begin{array}{l}\text { refers to the number of rooms (excluding kitchenette, scullery/utility room, } \\
\text { bathroom, toilet, garage, consulting rooms, office, shop) in a dwelling divided by } \\
\text { the number of persons living in the dwelling. }\end{array}$ \\
\hline 4 & $\begin{array}{l}\text { Household net adjusted } \\
\text { disposable income (US } \\
\text { Dollar) }\end{array}$ & $\begin{array}{l}\text { It's the maximum amount that a household can afford to consume without having } \\
\text { to reduce its assets or to increase its liabilities. }\end{array}$ \\
\hline 5 & $\begin{array}{l}\text { Household net financial } \\
\text { wealth (US Dollar) }\end{array}$ & $\begin{array}{l}\text { Net financial wealth consists of : currency and deposits, securities other than } \\
\text { share, loans, shares and other equity (including shares issued by investment } \\
\text { funds), insurance technical reserves, and other accounts receivable or payable, net } \\
\text { of household financial liabilities, as defined by the System of National Accounts } \\
\text { - SNA. Data refer to the sum of households and non-profit institution serving } \\
\text { households }\end{array}$ \\
\hline 6 & Employment rate (\%) & $\begin{array}{l}\text { It is the number of employed persons aged } 15 \text { to } 64 \text { over the population of the } \\
\text { same age. Employed people are those aged } 15 \text { or more who report that they have } \\
\text { worked in gainful employment for at least one hour in the previous week, as } \\
\text { defined by the International Labour Organization - ILO. }\end{array}$ \\
\hline 7 & Job security (\%) & $\begin{array}{l}\text { presents the probability to become unemployed. It is calculated as the number of } \\
\text { people who were unemployed in 2012, but were employed in } 2011 \text { over the total } \\
\text { number of employed in } 2011 \text {. }\end{array}$ \\
\hline 8 & $\begin{array}{l}\text { Long-term unemployment } \\
\text { rate }(\%)\end{array}$ & $\begin{array}{l}\text { refers to the number of persons who have been unemployed for one year or more } \\
\text { as a percentage of the labour force }\end{array}$ \\
\hline 9 & $\begin{array}{l}\text { Personal earnings (US } \\
\text { Dollar) }\end{array}$ & $\begin{array}{l}\text { refers to the average annual wages per full-time equivalent dependent employee, } \\
\text { which are obtained by dividing the national-accounts-based total wage bill by the } \\
\text { average number of employees in the total economy, which is then multiplied by } \\
\text { the ratio of average usual weekly hours per full-time employee to average usually } \\
\text { weekly hours for all employees. }\end{array}$ \\
\hline 10 & $\begin{array}{l}\text { Employees working very } \\
\text { long hours }(\%)\end{array}$ & $\begin{array}{l}\text { the proportion of dependent employed whose usual hours of work per week are } \\
50 \text { hours or more. This indicator measures the proportion of dependent employed } \\
\text { whose usual hours of work per week are } 50 \text { hours or more. }\end{array}$ \\
\hline
\end{tabular}

\section{Results}

\subsection{Effectiveness of the Russian population economic well-being}

Values of economic well-being indicators are presented in Table 2. We used the data of the OECD Better Life Index to compare the Russian population economic well-being with foreign countries [13].

Table 2. Values of the economic well-being indicators for the 2014

\begin{tabular}{lllllllllll}
\hline & \multicolumn{10}{c}{ Indicators } \\
\hline Country & 1 & 2 & 3 & 4 & 5 & 6 & 7 & 8 & 9 & 10 \\
\hline France & 0.5 & 21 & 1.8 & 2.9322 & 4,7668 & 0.64 & 6.5 & 3.98 & 3.8625 & 8.71 \\
Germany & 0.9 & 21 & 1.8 & 3.0721 & 4.9484 & 0.73 & 3.2 & 2.52 & 4.1782 & 5.6 \\
United States & 0.1 & 19 & 2.3 & 3.9531 & 13.2822 & 0.67 & 6.3 & 2.36 & 5.4214 & 11.4
\end{tabular}


eISSN: 2357-1330

Selection \& Peer-review under responsibility of the Conference Organization Committee

\begin{tabular}{lllllllllll} 
OECD - Total & 2.1 & 21 & 1.6 & 2.3938 & 4.2903 & 0.65 & 5.3 & 2.73 & 4.101 & 8.82 \\
Russia & 15.1 & 11 & 0.9 & 1.723 & 0.3331 & 0.69 & 4 & 1.69 & 2.1311 & 0.17 \\
\hline
\end{tabular}

These data show a serious lag between Russia and foreign countries on certain indicators (\#1, 2, 5, 9, 10). At the same time, there are three indicators (\# 6, 7,9) on which the level of Russia economic well-being is comparable with selected foreign countries.

The second direction of the effectiveness analysis implies the estimation of the indicators dynamics over time. Unfortunately, we had available statistical data for only the period of 2013 and 2014. The best results this method provides for significant time intervals. Growth rates of the indicators are presented in Tab. 3 and graphically summarized in Fig. 1.

Table 3. Growth rates of economic well-being indicators for the period $2013-2014, \%$

\begin{tabular}{|c|c|c|c|c|c|c|c|c|c|c|}
\hline \multicolumn{11}{|c|}{ Indicators } \\
\hline Country & 1 & 2 & 3 & 4 & 5 & 6 & 7 & 8 & 9 & 10 \\
\hline France & 83 & 100 & 100 & 104 & 102 & 100 & 70 & 104 & 103 & 97 \\
\hline Germany & 100 & 100 & 100 & 107 & 110 & 100 & 39 & 89 & 106 & 104 \\
\hline United States & & 100 & 100 & 104 & 115 & 100 & 55 & 84 & 100 & 103 \\
\hline OECD - Total & 95 & 100 & 100 & 104 & 106 & 98 & 50 & 87 & 119 & 101 \\
\hline Russia & 539 & 100 & 100 & 113 & 22 & 101 & 38 & 78 & 108 & 106 \\
\hline
\end{tabular}

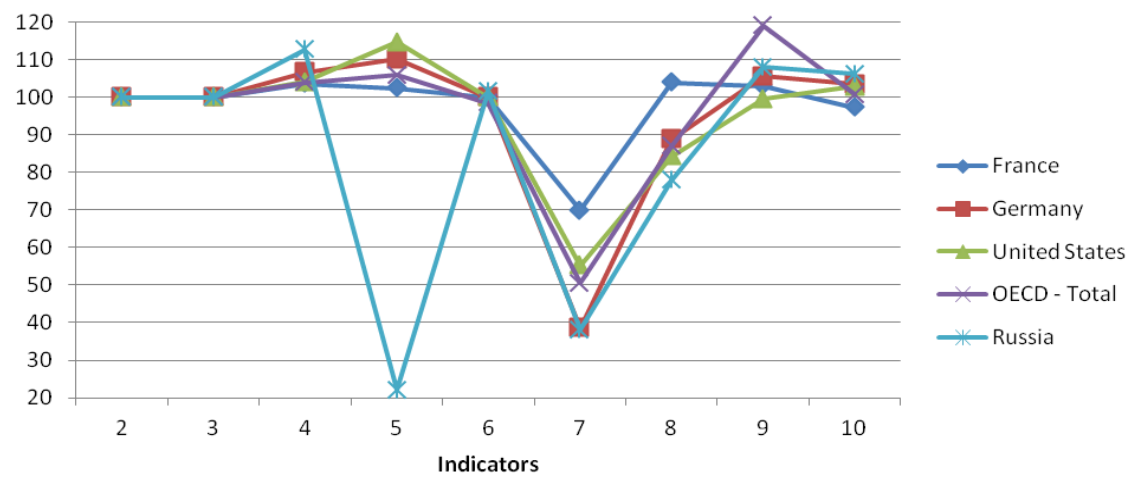

Fig. 1. Growth rates of economic well-being indicators for the period 2013-2014, \%

From the presented data, we can make several conclusions:

- Russia reduced the lag from the foreign countries by the part of indicators $(\# 3,6,7,8,10)$;

- changing the values of the two indicators $(\# 1,5)$ occurred probably by the reason of change the methods of their assessment in Russia;

- Russia reduced the lag from developed countries, but increased the lag from the average for the OECD countries by the indicator \# 9 .

Using the effectiveness analysis of Russian population economic well-being we found on the one hand, the strong lag from foreign countries by a number of indicators, on the other hand - some positive trends to reduce the backlog by most indicators. 
http://dx.doi.org/10.15405/epsbs.2016.02.57

eISSN: 2357-1330 / Corresponding Author:

Selection and peer-review under responsibility of the Organizing Committee of the conference

\subsection{Optimality of the Russian population economic well-being}

Analysis of the optimality allowed ranking the indicators by the degree of backwardness of Russia from foreign countries (Tab. 4, Fig. 2).

Table 4. Ratio of the indicators values between Russia and foreign countries for $2014, \%$

\begin{tabular}{lllllllllll}
\hline & \multicolumn{1}{c}{ Indicators } \\
\hline Country & 1 & 2 & 3 & 4 & 5 & 6 & 7 & 8 & 9 \\
\hline Russia / France & 3020 & 52 & 50 & 59 & 7 & 108 & 62 & 42 & 55 & 2 \\
Russia / Germany & 1678 & 52 & 50 & 56 & 7 & 95 & 125 & 67 & 51 & 3 \\
$\begin{array}{l}\text { Russia / United } \\
\text { States }\end{array}$ & 15100 & 58 & 39 & 44 & 3 & 103 & 63 & 72 & 39 \\
$\begin{array}{l}\text { Russia / OECD - } \\
\text { Total }\end{array}$ & 719 & 52 & 56 & 72 & 8 & 106 & 75 & 62 & 52 \\
\hline
\end{tabular}

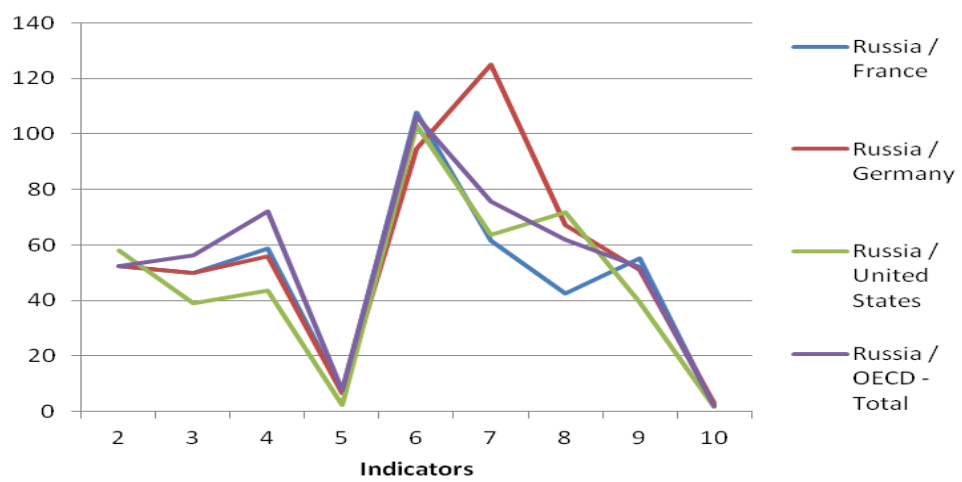

Fig. 2. Ratio of the indicators values between Russia and foreign countries for $2014, \%$

The strongest lag was by indicators \# 10, 5, 1. The lag on these indicators varies from 100 to 7 times. For some of them (indicators \#1 and \#10) the lag of Russia can be explained by its tradition and cultural characteristics. But the index \#5 "Household net financial wealth" is purely a financial measure and it reflects the extremely low level of financial stocks among the population of Russia.

By the other indicators the lag of Russia does not exceed usually 2 times, although this gap is also much.

The next two lines of optimality analysis are focused on the study of differentiation between groups of population:

- People with differentiation by sex;

- - Leading group and lagging group of population.

The results of the optimality analysis on population differentiation by sex are presented in Tab. 5 .

Table 5. Ratio of the indicators values between the population groups (male / female) for $2014, \%$

\begin{tabular}{lllllllllll}
\hline & \multicolumn{10}{c}{ Indicators } \\
\hline Country & 1 & 2 & 3 & 4 & 5 & 6 & 7 & 8 & 9 & 10 \\
\hline France & 100 & 100 & 100 & 100 & 100 & 113 & 94 & 101 & 124 \\
Germany & 100 & 100 & 100 & 100 & 100 & 115 & 103 & 118 & 123 & 337
\end{tabular}


eISSN: 2357-1330

Selection \& Peer-review under responsibility of the Conference Organization Committee

$\begin{array}{lcccccccccc}\text { United States } & 100 & 100 & 100 & 100 & 100 & 116 & 103 & 107 & 127 & 244 \\ \text { OECD - Total } & & & & & & 128 & 100 & 99 & 126 & 241 \\ \text { Russia } & 100 & 100 & 100 & 100 & 100 & 114 & 119 & 109 & 120 & 400\end{array}$

Significant differences of the indicator values between men and women are not observed. In Russia the differences are at the level of foreign countries. The only exception is an indicator №10. In the foreign countries and Russia men worked overtime more than 50 hours a week more often than women. In Russia this differentiation is expressed significantly stronger than in the other countries, but this can be explained by the low value of this indicator in Russia.

The results of the optimality analysis on population differentiation between the leading and the lagging groups are presented in Tab. 6.

Table 6 . Ratio of the indicators values between the leading and the lagging population groups for $2014, \%$

\begin{tabular}{lllll}
\hline & \multicolumn{3}{c}{ Indicators } & \\
\hline Country & 4 & 6 & 8 & 9 \\
France & 454 & 180 & 36 & 215 \\
Germany & 430 & 191 & 18 & 211 \\
United States & 792 & 235 & 26 & 295 \\
OECD - Total & 491 & 170 & 41 & 248 \\
Russia & 590 & 296 & 29 & 241
\end{tabular}

Only four from ten indicators are available for the analysis. Their numbers is used in accordance with Tab. 1. In general, the indices differentiation of Russia is comparable with other countries. However, we found certain advantages of the leading group in Russia. These advantages consist of larger excess of the average income over the lagging group (indicator \#4), higher employment rate and lower probability of lost a job for a long time (indicator \#6, 8). On these indicators the gap between the leading and the lagging groups for Russia is higher than for the foreign countries.

According these results we compared the indicators of the lagging group in Russia with the lagging groups in the other countries (Tab. 7). We calculated the ratio of the indicators values between Russia and the foreign countries for the entire population and the lagging group and presented them on Fig. 3.

Table 7. Ratio of the indicators values between Russia and foreign countries (the lagging group) for 2014, \%

\begin{tabular}{lllll}
\hline & \multicolumn{3}{c}{ Indicators } & \\
\hline Country & 4 & 6 & 8 & 9 \\
Russia / France & 45 & 62 & 59 & 49 \\
Russia / Germany & 43 & 61 & 68 & 44 \\
Russia / United States & 53 & 82 & 73 & 47 \\
Russia / OECD - Total & 62 & 60 & 91 & 55 \\
Russia / France & 45 & 62 & 59 & 49 \\
\hline
\end{tabular}



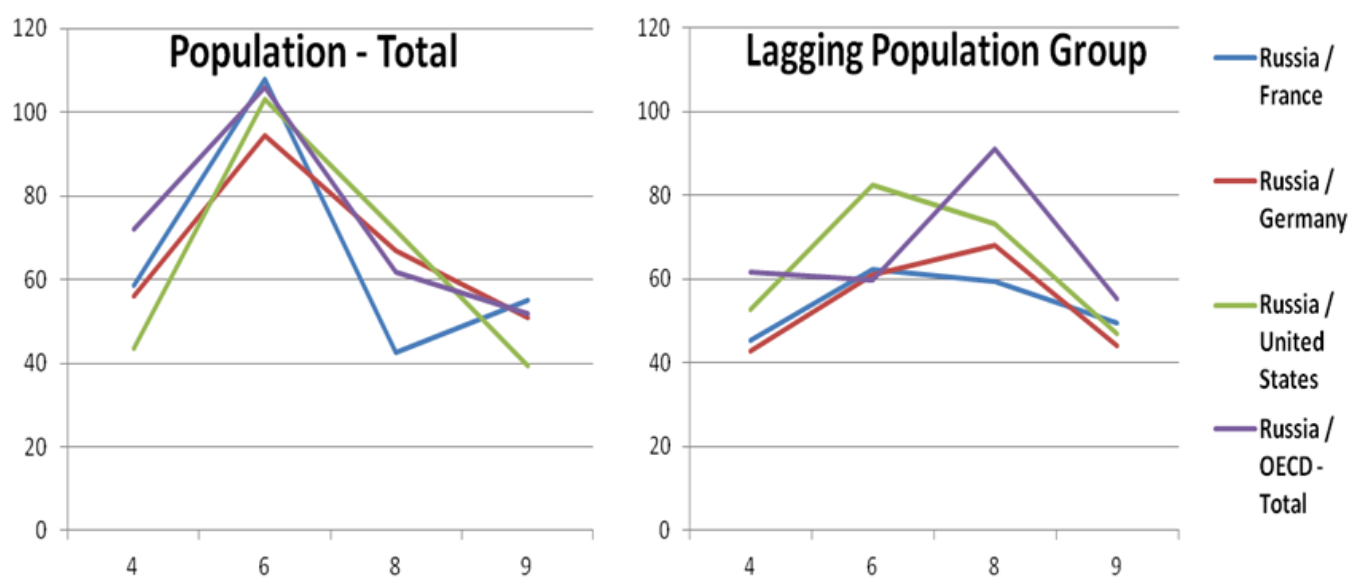

Indicatiors

Fig. 3. Ratio of the indicators values between Russia and foreign countries for $2014, \%$

We found that the lagging group of the Russian population has lower ratios of the indicators values with foreign countries than the total population of Russia by three of the four available indicators (\#4, $6,8)$. It means that the gap between the leaders and the outsiders groups in Russia is higher than in the other countries for most of the available indicators.

Using the optimality analysis of economic well-being we found that Russia lagged far behind the level of foreign countries (7-100 times) by the indicators \#10, 5, 1. There were no significant differences in the values of indicators between men and women for Russia and the foreign countries (excluding index \#10). It was found that the gap between the indicators values of the leading and the lagging groups in Russia is higher than in the foreign countries (indicators \#4, 6, 8). The lagging group of the Russian population has lower ratios of the indicators values with foreign countries than the total population of Russia.

\section{Conclusions}

We tested the method of complex efficiency estimation to solve the problem of economic wellbeing analysis. We assessed the effectiveness and optimality of economic well-being of the population.

Using the effectiveness analysis of Russian population economic well-being we found on the one hand, the strong lag from foreign countries by a number of indicators, on the other hand - some positive trends to reduce the backlog by most indicators.

Using the optimality analysis of economic well-being we found the following:

- Russia lagged far behind the level of foreign countries (7-100 times) by the indicators \#10, 5, 1;

- there were no significant differences in the values of indicators between men and women for Russia and the foreign countries (excluding index \#10);

- the gap between the indicators values of the leading and the lagging groups in Russia is higher than in the foreign countries (indicators \#4,6,8). The lagging group of the Russian population has lower ratios of the indicators values with foreign countries than the total population of Russia. 
The results of the economic well-being analysis are advisable to consider in the process of state regulation in Russia. State support of social services should be a priority of social and economic policy on the federal and regional authorities. Our analysis justifies the recommendation to reduce the gap between rich and poor groups of Russia's population by using various regulatory tools, including a progressive scale for a number of taxes. In particular, it seems appropriate to set the progressive scale of tax on personal income, insurance contributions to social funds, taxes on personal property, etc.

\section{Acknowledgements}

This work was performed by the authors in collaboration with Tomsk Polytechnic University within the project in Evaluation and enhancement of social, economic and emotional wellbeing of older adults under the Agreement No.14.Z50.31.0029

\section{References}

Diener, E., \& Biswas-Diener, R. (2002). Will money increase subjective well-being? Social Indicators Research, 2, 119-169.

Diener, E., Lucas, R.E., Schimmack, U., \& Helliwell, J. (2009). Well-being for public policy. New-York: Oxford University Press.

Dolan, P., Peasgood, T., \& White, M. (2008). Do we really know what makes us happy? A review of the economic literature on the factors associated with subjective well-being. Journal of Economic Psychology, 29, 94-122.

Easterlin, R.A. (2001). Income and Happiness: Towards a unified theory. Economic Journal, 111, 1-20.

Ferrer-i-Carbonell, A. (2005). Income and well-being: an empirical analysis of the comparison income effect. Journal of Public Economics, 89, is. 5-6, 997-1019.

Sarracino, F. (2013). Determinants of subjective well-being in high and low income countries: Do happiness equations differ across countries? The Journal of Socio-Economics, February, 51-66.

Mentzakis, E., \& Moro, M. (2009). The poor, the rich and the happy: Exploring the link between income and subjective well-being. Journal of Socio-Economics, 38 (1), 147-158.

Han, Ch. (2015). Explaining the subjective well-being of urban and rural Chinese: Income, personal concerns, and societal evaluations. Social Science Research, January, 179-190.

Akter, S., \& Basher, S.A. (2014). The impacts of food price and income shocks on household food security and economic well -being: Evidence from rural Bangladesh. Global Environmental Change, 25, March, 150-162.

Rajan, K., Kennedy, J., \& King, L. (2013). Is wealthier always healthier in poor countries? The health implications of income, inequality, poverty, and literacy in India. Social Science \& Medicine, 88, July, 98-100.

Spitsina, L.Yu., \& Spitsin, V.V. (2015)Assessing the complex efficiency of socio-economic well-being of the population for government regulation purposes. Economic Analysis: Theory and Practice, 16, 16-25.

Spitsin, V.V., \& Monastirniy, E.A. (2014). Assessing the efficiency of innovation development at macro and meso-levels: a methodology and practice. Tomsk: Tomsk Polytechnic University Publ.

OECD.Stat Extracts. Available at: http://stats.oecd.org/\# 